\title{
Knightly Effigies at Sandwich and Ash
}

\section{J. Hewitt}

To cite this article: J. Hewitt (1851) Knightly Effigies at Sandwich and Ash, Archaeological Journal, 8:1, 291-306, DOI: 10.1080/00665983.1851.10850827

To link to this article: http://dx.doi.org/10.1080/00665983.1851.10850827

曲 Published online: 10 Jul 2014.

Submit your article to this journal $\widetilde{ }$

Q View related articles $₫$ 


\section{KNIGHTLY EFFIGIES AT SANDWICH AND ASH.}

There are few spots in all England more interesting to the historian and the archaeologist than Sandwich and its neighbourhood. On one side is Richborough, the Roman gate of Britain, even now magnificent in its extensive remains. On another side are found the monuments of Anglo-Saxon occupation: graves, arms, domestic utensils, and articles of personal adornment. The churches of Ash and Sandwich are rich in the sculptured effigies of medieval knighthood. Sandwich itself is most curious as a landmark of passing centuries, a "Bauta-stone," set up by Time, to record how seaport after seaport has been destroyed by the "aboundance of the light sande driven in by the sea." The narrow, tortuous streets, have clearly not changed their groundplan since the days when Edward the Third assembled at this spot his army of " 3000 lances and 10,000 archers, with a fleet of 400 sail," and when Edward the Black Prince landed here with the King of France as his prisoner. In the quaint old houses of post-and-pane, we see the very homes of the refugee Flemings, settled here with their weaving arts in the sixteenth century; and amongst these buildings probably yet remains the very mansion occupied by Queen Elizabeth in her stately progress to the renowned cinqueport: "Mr. Manwood's house, wherein she lodged, a house wherein Kinge Henry the VIIIth had been lodged twyce before ;" where she was presented with " a cupp of gold of a hundredth pounds, and a New Testament in Greeke, which she thankfully accepted ;" and where, on "a scaffold made uppon the wall of the scole house yarde," were seen divers "Englishe and Dutche, to the number of Cth or VI score, all spynning of fyne baye yarne, a thing well lyked both of her Majestie, and of the Nobilitie and ladies." 1 And not least interesting and instructive to the archaeologist and the historian is the rare collection of

\footnotetext{
${ }^{1}$ One cannot help comparing and curiously considering the very similar scene which has bcen enacted under our own eyes within this passing month $\rightarrow$ Queen

rOL. VIII.
}

Victoria at the Crystal Palnce examining the Department of "Machinery in motion." 
Roman and Anglo-Saxon antiquities, formed at Sandwich by D. Rolfe, Esq. ; a collection which, in itself of the highest interest, becomes a source of gratification from the courtesy with which it is exhibited by its possessor.

Among the knightly effigies of Sandwich and Ash, are two which are especially curious; one from the armour being composed in part of scale-work, and the other from offering an example, among the very few in monumental sculpture, of "ailettes" attached to the warrior's equipment. The Sandwich figure is preserved in the Church of St. Peter, at the west end of the nave. Though clearly of the first half of the fourteenth century, it has been traditionally assigned to $\mathrm{Sir}$ John Grove, who lived in the middle of the fifteenth. The statue originally reposed on an altar-tomb in the south aisle; on the demolition of that aisle by the falling of the steeple in 1661 , it was exposed to every manner of depredation, whether from the assaults of the weather, or "the trampling of boys," and subsequently, at the instigation of the historian of Sandwich, it was brought within the body of the Church and placed in the situation it now occupies. The outer (or left) side of the figure having been much injured, says Boys in his History, "I have reversed its position and brought to view the other" parts, where the sculpture is remarkably sharp." Search was at the same time made for the remains of the knight, but none being found, it was concluded that they were removed into the interior of the Church at the demolition of the aisle. In Le Neve's Church Notes, (begun in 1603,) the tomb is described as that of Sir John Grove, and on the tomb-side appear the arms of Grove, Septrans, St. Leger, Hilparton, Isaac and Sandwich, while the arms of Grove are repeated on the shield. (Add. MS. in Brit. Mus., No. 5479, f. 89.) As these arms were in paint only, their evidence is of no great value. From the effigy itself all trace of pictorial decoration has disappeared.

The size of the remaining fragment is $4 \frac{1}{2}$ feet; the material Caen stone. The art is somewhat rude, but the details are made out with great care. The figure does not seem to have suffered in the slightest degree since the time of $\mathrm{Mr}$. Boys, and it is now kept with the greatest care. The lnight wears the quilted gambeson; over that a hauberk of chain-mail ; then a defence of scale-work; and above that 


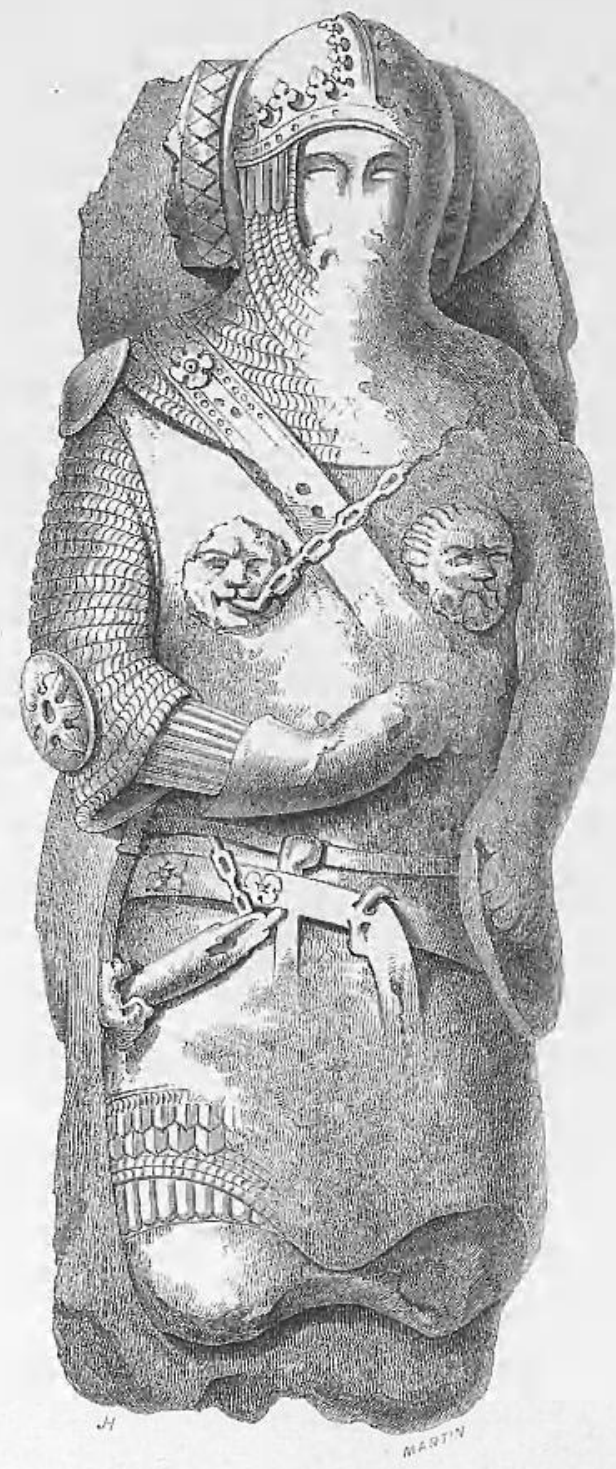

Emgy in St Peter's Church, Sandwich. 
the fringed sleeveless surcoat, girt at the waist with a narrow belt, which serves also to sustain the dagger. The particular object of placing a third "coat of fence" between the hauberk and surcoat is not altogether clear to our modern perceptions, but the usage is sufficiently frequent to show that it met the approval of those who were best qualified to pronounce upon its merits. In the effigies of John of Eltham, of Sir Oliver Ingham, and of Sir Humfrey Littlebury, (Stothard's Monuments, Plates 55, 66, and 75,) we find a bezanted garment between the hauberk and surcoat. The brass of Sir John D'Aubernoun, (Stothard, Pl. 60,) and that of De Creke, (Waller, Pt. 8,) exhibit a studded pourpoint in the same position. The effigy in Ash Church (Stothard, Pl. 61) has a quilted gambeson thus worn. The statue of a Pembridge (Hollis, Pt. 5) has a garment similarly placed; and in the figure of Albrecht von Hohenlohe, (Hefner's Trachten, Pt. 2, Pl. 87) we observe at the shoulders a defence of scale-work interposed between the surcoat and the hauberk of chain-mail.

On the arm of our knight is seen a portion of the gambeson, and over that the loose sleeve of the hauberk, furnished with rondelles at the elbow and shoulder. These rondelles were frequently attached to the hauberk with points. Instances occur in the brass of Sir John D'Aubernoun, (Stothard, Pl. 60,) in the marble effigy of an Italian knight at Naples, (Hefner, Pt. 2, Pl. 33,) in the brass of William Wenemaer at Ghent, (Arch. Journal, vol. vii., p. 287,) and in some of the illuminations of Roy. MS., 16, G. VI. The gauntlets have received too much injury for their construction to be detected: they were probably of leather, armed with strips of steel. The " bassinet rond," with its pendents and ornaments in relief, bears a close resemblance to the neighbouring example at Ash, figured by Stothard, Pl. 61. The pendents here are ridged : therefore probably of metal or cuir-bouilli. Compare also the effigy at Ifield (Stothard, Pl. 59). The camail of chain-mail offers no peculiar feature. The linightly belt and the cross-belt (q. the guige ?) are richly ornamented with studs and rosettes. The mamellieres have the form of lion's heads: the chain from the right one appears of inconvenient length to be attached to the lower part of the helm, though such was its usual purpose. The dagger hilt is secured by a chain, while a 
cord suspends the sheath: the guard is formed by two knobs, though now nearly obliterated by damages of time and wantonness. The leg defences are no longer to be defined, and the shield (observed by Le Neve) has totally disappeared. The action of the figure appears to be that of sheathing the sword. The slab beneath the effigy is of the coped form.

The scales, which form the most remarkable part of this harness, are ridged; therefore they were probably of metal or cuir-bouilli. Though occurring in comparative infrequency on the monuments of the middle ages, examples of scalearmour are not wanting in all times, from the epoch of the Nimroud sculptures to that of our own commonwealth ; and indeed later, for the Asiatic contributions to the "Great Exhibition" show us that even to this day, the "lorica squamata" is occasionally worn in the east.

The Assyrian sculptures in the British Museum offer
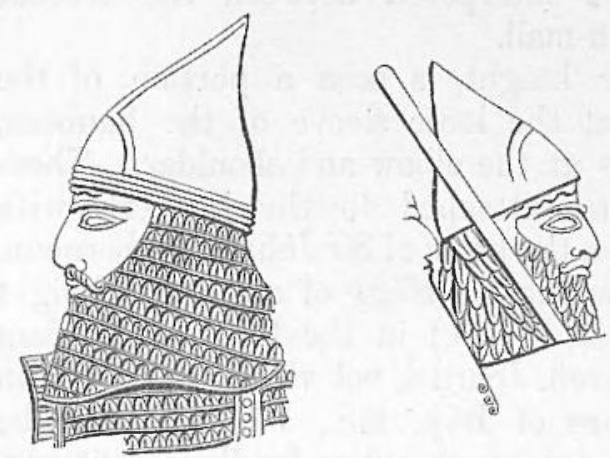
numerous examples of scale-armour. The two figures here given aro from Layard's large work on these monuments, Pls. 17, and 18. It will be remarked that the arcs of the scales are not set in the same direction in both cases : the figure with the staff is also curious in the addition of a chin-band, which seems to fasten his helmet over the gorget. In the second figure one cannot fail to be struck with the curiously close resemblance of the defences to the camailed bassinet of the European knight of the fourteenth century. Mr. Layard considers these scales to have been "fastened to bands of iron or copper." (Ninereh and its Remains, ii. 336.) Several of the real scales were discovered, and are deposited in the British Museum. The one here given has been carefully drawn from the original. It is of iron, three inches in length; the ridge, which is raised in front, is hollow behind; the apertures for fastening appear to have been obliterated by the oxidation of the metal. Some of the scales were inlaid with copper, and these, 
Mr. Layard suggests, "were probably fastened to a shirt of felt or coarse linen." (Nineveh, ii. 335.)

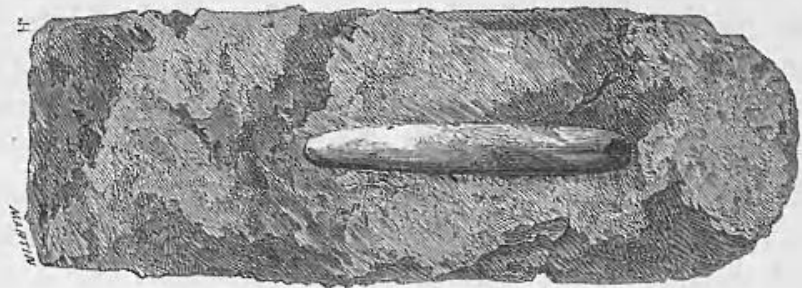

Of the scale-armour worn by the Egyptians a remnant has been found, and is preserved at Cairo, in the collection of Dr. Abbott. It has been figured in the superb work of Prisse d'Avennes (Pl. 46), and again in the Revue Archléologique (ii. 735). Our cut is from the plate in the former volume.

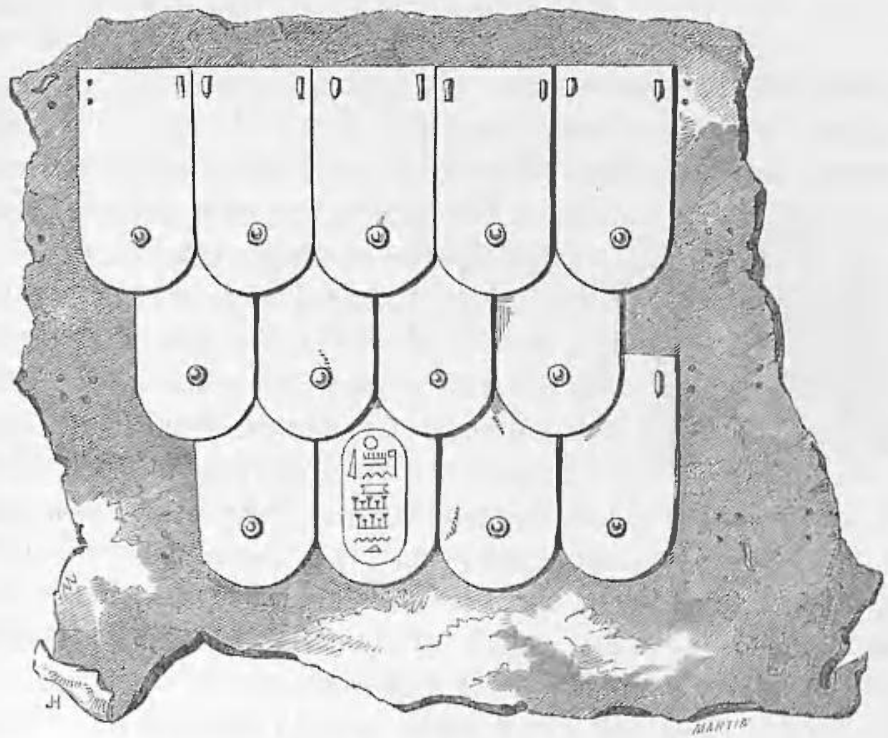

In the latter, it is described as "un fragment de cuirasse formée d'écailles de bronze superposées et cousues sur du cuir, et tout-à-fait semblables a celles qui sont peintes dans une des petites salles du tombeau de Ramses-Meiamoun et dans d'autres hypogées. Chacune de ces écailles, qui a environ 35 millimetres de hauteur sur 20 de largeur, est 
repoussée vers le milieu de manière à présenter l'aspect d'une rivure. Mais ce qui ajoute beaucoup de prix $\dot{a}$ ce morceau deja si curieux, c'est le cartouche de Scheschonk, le Sesak de la Bible, gravé sur une de ces écailles. Cette cuirasse a ete trouvée dans un hypogée de la haute Egypte."

Examples of scale-armour during the classic period are of too frequent occurrence in the sculptures, the paintings and other monuments of this time, to need a particular enumeration. The plates of Hope's Costumes furnish many beautiful instances, and in the British Museum the charming bronze statue of Mars, found in the Falterona lake, should not be overlooked. See also a second statuette of Mars, figured in the useful Handbook to the Antiquities of the Museum, lately published by Mr. Vaux. Specimens of scalearmour of this age are of the greatest rarity. A fragment unquestionably of Roman manufacture claims especial notice, as having been found in England. It was discovered with various objects of the Roman age, fibulæ, and ornaments of bronze, fragments of "Samian" ware, and other relics undoubtedly assignable to that period, disinterred in the course of excavations recently directed by Sir William Lawson, Bart., at the site of the station of Cataractonium,

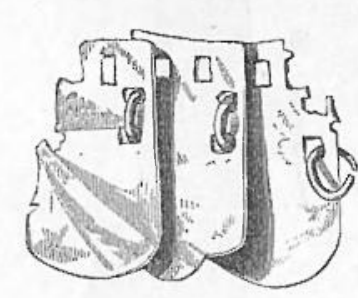
in Yorkshire, on the southern bank of the Swale, at Catterick bridge.

The material is bronze : each scale is attached to its fellow by a little bronze ring, a contrivance which appears to secure flexibility to the garment without greatly impairing its compactness. The apertures in the

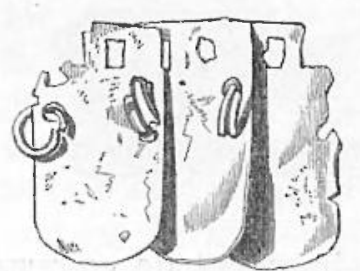

Fragment of bronze scale-al'mour, found near Catterick, Yorkshire. (Orig. size.) upper part of the scales are clearly for the purpose of lacing them to the basis of leather or other material which held the whole together. We are indebted to the kindness of Mr. Albert Way, for the accompanying sketch of this interesting relic, to whom also we owe that it has been brought into notice, and assigned to its proper class among the vestiges of Roman Britain. It is interesting to compare this little relic with the curious scaled defence, of which a fragment was found at Pompeii, and is 
represented in $\mathrm{Mr}$. Rich's excellent manual, the "Illustrated Companion to the Latin Dictionary," p. 392, (v. Lorica). The material in that example is, however, bone, the plates being united by metallic rings.

One is strongly tempted to believe that this is the very armour described by various Roman writers, in passages which have hitherto greatly puzzled the commentators; by Silius Italicus, for instance, who, in his fifth book, thus describes a coat of scaly-mail:

" Loricam induitur tortos huic nexilis hamos

Ferro squama rudi, permistoque asperat auro."

And by Claudian, who, in his second book, has:

"Flexilis inductis hamatur lamina membris, Horribilis visu. _—"

And again by Virgil, who, in the third book of Aineid, writes :

"Loricam consertam hamis, auroque trilicem."

Among the northern nations, armour of scale-work was probably worn by leaders; but the descriptions of the Sagas and other writings are so vague, that it seems impossible to derive any satisfactory conclusion from their testimony. And, unluckily, existing remains do not offer their aid to clear the mystery. "Among the most usual weapons of defence," writes Mr. Worsaae, in his Primeval Antiquities of Denmark, "the ancient Sagas mention helmets, coats of mail, armour, and shields. The fact that of the three firstnamed objects scarcely any relics at all have reached us, is by no means difficult to explain. The helmets were probably in most cases only the skins of the heads of animals, drawn over a framework of wood or leather, as the coat of mail was usually of strong quilted linen, or thick woven cloth. Lastly, the armour which covered the breast was formed, it is true, of metal, either in iron rings attached to each other, or of plates fastened on each other like scales ; but it certainly was only a few individuals who had the means and opportunity of obtaining such expensive objects." The numerous Anglo-Saxon illuminations exactly confirm this view; in them we see clearly that it was the chiefs only who had the benefit of the Brünne, but the rudeness of the delineation, still leaves us in doubt as to the 
construction of the armour. In the twelfth century, however, we find the Emperor Henry V. clothing a body of his troops in an impenetrable scale-armour of horn (das Hornschuppenwamms). "So trug im Jahre 1115 eine Schaar im Heere Heinrichs V. undurchdringliche Harnische von Horn." (Raumer's Hohenstauf. - in Von Leber's Wien's Kaiserliches Zeughaus, p. 507.) And in the poem of "Wigalois," written about 1212, we have a most curious description of this horn-mail worn over the hauberk, and richly adorned with gold and precious stones:

" Ein brunne het er an geleit

Uber einen wizzen halsperch.

Daz was heidenischez werch

Von breiten blechen hurnin;

Mit golde waren geleit dar in

Rubin, und manee edel stein

Der glast da wider einander schein

Saffire und berillen. _-_"

It has been usual to describe the seal of William Rufus as exhibiting scale armour ; and in the new Foedera these scales have been rendered in the most emphatic manner. The armour on the seal itself is distinctly of rings, and probably is meant to represent the perfect fabric of chainmail so familiar to us throughout the succeeding centuries. Many seals of this time are in the same predicament. In the thirteenth and fourteenth centuries the scale defences are of occasional appearance, and the Cotton MS., Claudius, D. II., at fol. 30, furnishes us with a curious example of this period, a soldier armed with a "tunicle of scale," which extends from his shoulders to his waist, lying loosely over him like a modern cape or tippet.

In the knightly harness of this time scale-work appears to have been used for parts only of the defences; as the gloves, the sleeves, the sabatyns, or the skirt of the cuirass. Drawings, indeed, occur in which scale-like forms cover the whole person, as in the Louterell Psalter, but it is not unlikely that this is only a conventional mode of depicting chain-mail. The three examples subjoined are from monumental brasses; in each case the kinightly panoply has no other portion of scale than what is here exhibited. The gauntlets are from the effigy of a De Buslingthorpe, at Buslingthorpe, Lincolnshire, c. 1280 (Waller, Pt. 10). The vambrace of ridged scale, overlajd by a loose sleeve of 
banded mail, is from the well-known brass at Minster, Isle of Sheppey, c. 1337 (Stothard, Pl. 54). The sabatyns appear on the brass of Sir Wm. Cheyne, A.D. 1375 (Waller,

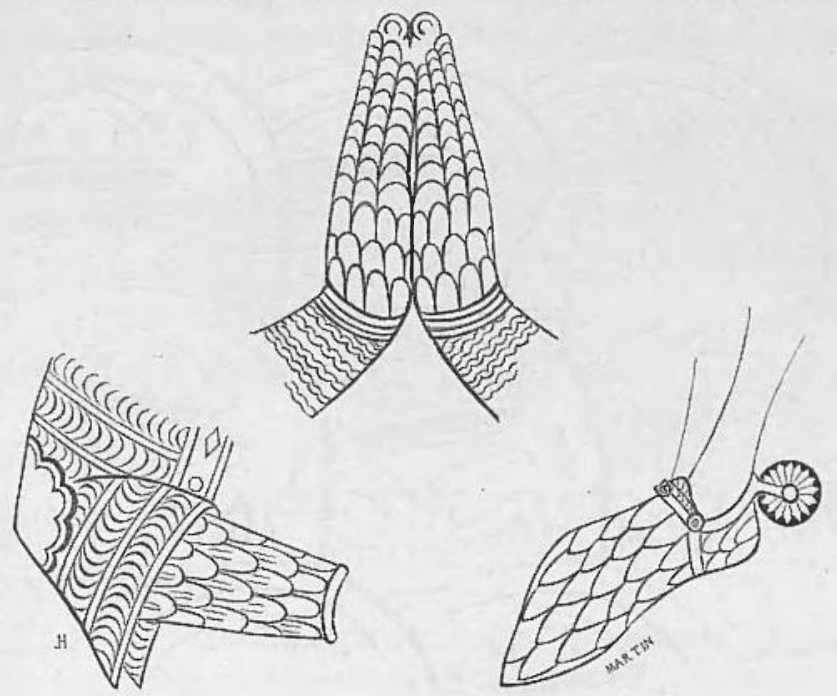

Pt. 8). Similar scale boots are seen on an effigy figured in Hyett's Northamptonshire Monuments, and on that of a De Vere, at Earl's Colne, given in Powell's Essex Collections (British Mus., Add .MS., 17,460). "Petticotes" of scale occur in the illuminations of the "Roman du roy Meliadus," c. 1375 (Add. MS. 15,228, ff. 274, 275) ; in two German monumental sculptures given by Hefner, dated 1407 and 1421 (Trachten, Pt. 2, Plates 92 and 110); and in the picture of a mounted knight on folio 161 of Harl. MS., 4374, a work of the second half of the fifteenth century. In the sixteenth century, scale appears in the Elrenpforte of the Emperor Maximilian I., forming headpieces and "bases" of the soldiery ; and in Hans Scheffelein's cuts to the romance-poem of Tewrdannckh, similar skullcaps are seen. In the picture of the Battle of the Spurs, at Hampton Court, there is the figure of a horse wearing a defence of scale-work over his neck. Later, we have the costly suit, in the Tower, of Count Hector Oddi, of Padua, of which we give a portion in its natural size. (See next page.)

The armour is a demi-suit, the culet alone being of scalework. Each scale is fastened by two rivets to a basis of vor. viII. 
canvas and leather, the canvas next the metal. This example of real armour curiously illustrates those representations in the Nimroud sculptures where the scales are seen to overlap from below, an arrangement which appears to have been

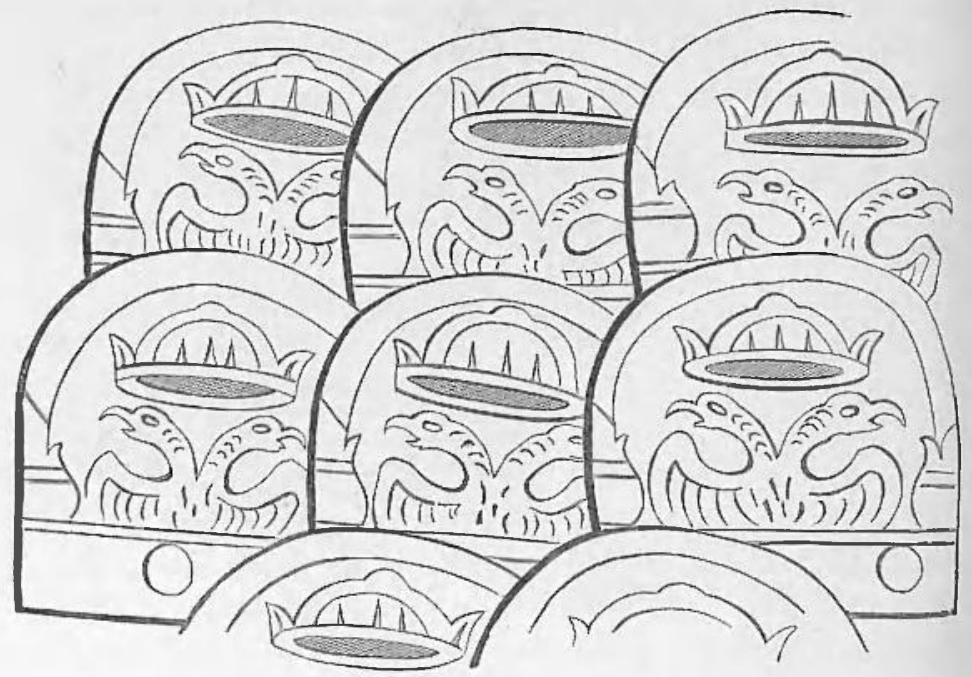

adopted in order that the pointed weapon of an assailant might glance off, instead of finding its way between the folds of the steel. A portion of scale-armour preserved in the "Bronze Room" of the British Museum, seems to be of this period; its structure is the same, steel rivetted on canvas and leather. Scale-work, of which the material is stout buff leather, is occasionally met with at this time. In Grose's Ancient Armour, Pl. 39, is figured "a buff covering for the left arm, contrived to answer the purpose of a shield, being composed of three skins of leather, with one of cartoon or pasteboard. To it is fixed a buff glove." It appears on the same plate with the buff coat, sword, \&c. " worn in the time of Charles I., by Sir Francis Rodes, Bart., of Balbrough Hall, Derbyshire." A buff glove of scale-work is in the collection at Goodrich Court ; ${ }^{2}$ and another, in the possession of the writer, is here engraved.

This example came from the Bryn-y-Pys collection, and was not improbably an ancestral relic. The buff scales are a quarter of an inch thick, extremely tough, and seem

2 By a note (since observed) in Meyrick's Crit. Inq., vol. iii., p. 87, it appears that the example at Goodrich Court is the very one figured by Grose. 
thoroughly proof against a sabre-cut. The portion that corers the hand itself (defended in fight by the basket-hilt of the sword of that day) is of the ordinary flexible leather. In the Dresden collection is a curious example of scale harness, the "Schuppenpanzer" of John Sobieski, king of

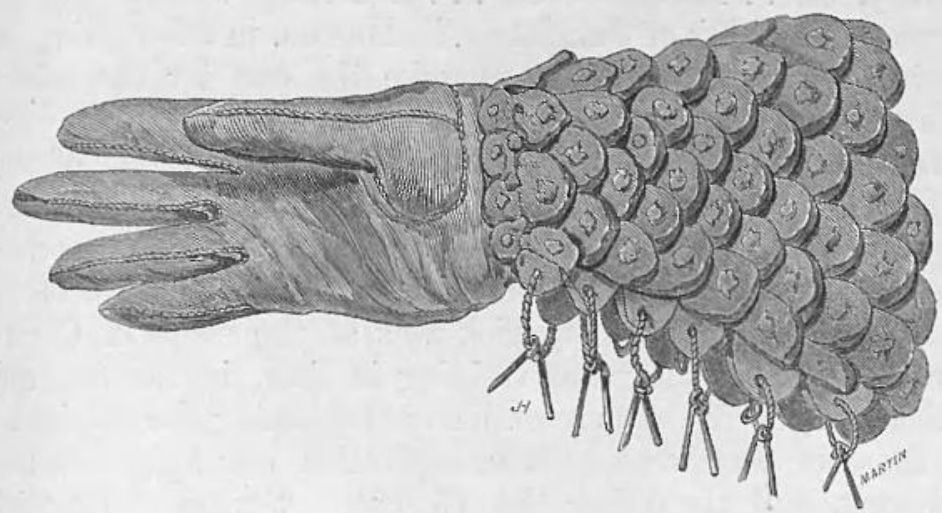

Poland, 1696. It consists of a coat with short sleeves, to which are added vambraces of plate. The helmet, which has a sliding nasal, and the gorget, are also of scale-work. The scales of the body are ensigned each with a gold cross, except a row in front, which has lions' heads in gold; all the rest are of plain steel. This singular armour is given in colours in Reibisch's Dresden "Rustlammer" Pl. 9, fig. 28. The modern Asiatic scale-coat in the Indian department of the Great Nations-Exhibition, resembles the above in its form (a body-dress with short sleeves), but all the scales are of plain steel. In the Tower may be seen another oriental example; a head-piece of steel scales, strengthened with bars of the same metal, which overlie the scales, and unite at the top. And at Goodrich Court is another; a Sikh armour, consisting of breast-guard and head-piece, the scales of which are formed of semi-transparent buffalo hide. It would not be difficult to multiply these examples, but our object has rather been to trace rapidly the persistence of this fashion of scale-arming from the earliest to the latest times, than to accumulate notices of specimens, or distinguish varieties of arrangement.

The curious effigy in the church of "Ash-by-Sandwich," to which we have already alluded, as affording one of the very few examples in monumental sculpture of the addition of 
ailettes to the knightly suit, occupies an altar-tomb between the chancel and the north chantry. The figure forming the subject of Stothard's 61st Plate, lies to the east of it. Weever notices these two cross-legged knights: "In this church are many ancient monuments of worthy gentlemen, namely, Sir ... Goshalls, Sir . . Leuericks, who lye crosselegged, as knights of Jerusalem." Hasted, in attempting to distinguish them, seems to mistake the one for the other. "In the north wall," he writes (Hist. of Kent, vol. iii., p. 692, note), " near the upper end, is a monument for one of the family of Leverick, with his effigies in armour, lying crosslegged on it; and in the same wall, westward, is another like monument for Sir John Goshall, with his effigies on it, in like manner." As Laverick was at the siege of Carlaverock, and Goshall "was residing in Ash, in Edward the Third's reign," it seems most likely (admitting the effigies to be those of the personages named) that our knight is the Laverick, and the other the Goshall. Several influential families, however, were fixed hereabout at this period, particularly the De Leyburnes, an heiress of whose house was styled, from her large possessions, "the Infanta of Kent." And " in the windows of the church of Ash were formerly painted several coats of arms, and among others, of Septrans, alias Harfiete, Notbeame, who married Constance, widow of John Septrans; Brooke, Ellis, Clitherow, Oldcastle, Keriell, and Hougham; and the figures of St. Nicholas, Keriell, and Hougham, kneeling, in their respective surcoats of arms; all which have been long since demolished." (Hasted, vol. ïi,, p. 693.)

The effigy of our knight is of life-size, the material, free-stone; the mail having been expressed in stucco. The sculpture is in moderately good condition, but the stucco has disappeared from all the exposed parts. The figure reposes on a flat slab, of which the edges are chamfered off. The first garment in view is the gambeson, quilted in vertical stripes; over that is the hauberk of chain-mail, which has been painted of a red-brown colour. The hands are bare, and appear to have held a heart, as in other examples of this period. The chausses are of chain-mail, painted as the hauberk. The genouilleres, ornamented with a cusped trefoil enclosing a three-leaved flower, retain traces of former gilding. The hoop-like form seen above the knee- 


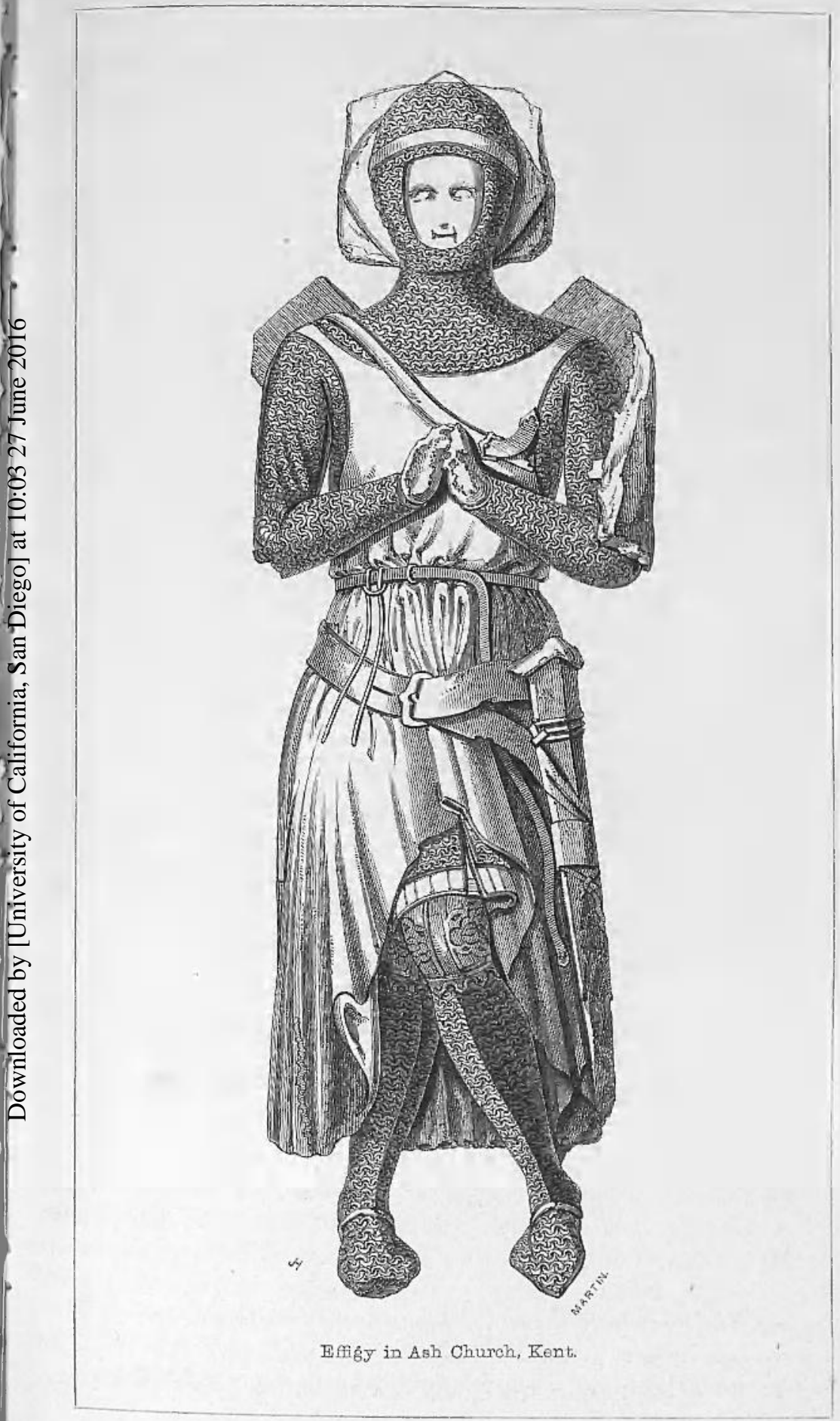


pieces appears to be part of the chausson. The spurs, of a single goad, with two straps, have been gilt. At the feet is a lion. The sleeveless surcoat is of great length, outcut in front for convenience of riding, and gathered in at the waist by a plain narrow belt; on its surface may be traced portions of black and gold, but in quantities too small to give any notion of the original heraldic decoration. Overlying the surcoat is the round-topped chain-mail hood, bound with a gilt fillet. The pillows beneath have been ornamented with a fret in purple and gold. The sword, much broken, is sustained by a broad belt, on which may be traced the faint outlines of a circular ornament. The cord attached to the waistbelt has borne a dagger, of which scarcely a fragment remains. The shield has nearly disappeared; it seems to have been triangular in form, and of moderate dimensions: it is attached by the usual guige. The ailettes appear behind the shoulders, rising from the slab beneath about the eighth of an inch: they have been quadrangular, though the outer corners are now broken off; they show no sign of fastening and no trace of colour.

The other monumental statues in England exhibiting the ailette, are those of a Pembridge in Clehongre church, Herefordshire (figured, with details, in Hollis's Monuments), and the so-called Crusader at Great Tew, Oxfordshire. ${ }^{3}$ The Clehongre figure is especially curious as showing the ailette fastened by a point, which appears on the outside. In Switzerland there is the statue of Rudolph von Thierstein, at Basle: the ailettes here are square, and fixed on the side of the figure. (Hefner's Trachten, Pt. 2, plate 41.) The examples offered by English monumental brasses are sufficiently familiar ; those of Septvans, Trumpington, and Buslingthorpe, are figured by Hollis, and the Gorleston brass by Stothard. The curious painted windows at Tewkesbury, given in full by Carter, and in part by Shaw (Dresses and Decorations), afford the best illustration contributed by pictured glass. In ivory-carving, and in seals, the ailette is of frequent occurrence. The seals of Edward the Third, as Duke and as King, are well-known instances. Illuminated the presence of ailettes is almost entirely confined to the reign of Edward the Second. 
manuscripts offer abundant examples; see, for instance, RI. MSS., 14, E. III., and 2, B. VII. The Louterell Psalter affords a fine specimen, copied in Carter's Sculpture and Painting, and in the Vetusta Monumenta. French monumental examples, we learn from M. Allou, are very scarce: "L'accessoire qui nous occupe est fort rare dans les monuments français. Nous en trouvons des exemples dans les dessins qui nous ont été communiqués par M. Achille Deville, des pierres sépulchrales de Robert Duplessis, 1322, de Robert d'Estouteville, 1331, et de Jean de Lorraine, Duc de Brabant, 1341." (Mem. de la Soc. des Antiq. de France, vol. xiii., p. 339.)

The forms of the ailette are various: the most frequent is the square. The round occurs on the ivory casket engraved in the fourth volume of the Journal of the Archæojogical Association; see also Plates 113 and 114 of Carter's Sculpture and Paint-

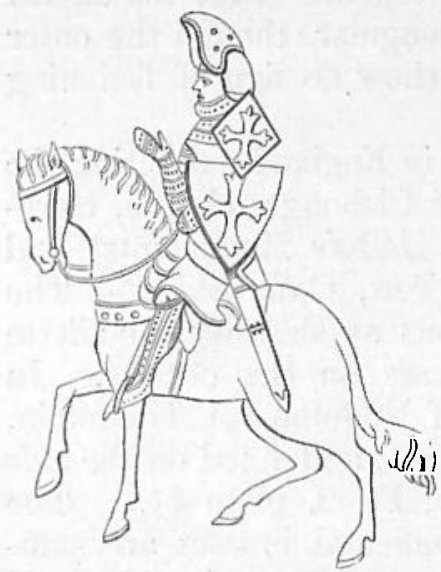
ing: the pentagonal is seen in an illumination of Sloane MS, 3983, engraved as the frontispiece to Strutt's Dress and Habits : the cruciform, in that curious figure of a kneeling knight in RI. MS. 2, A. XXII., fol. 219, figured by Strutt and by Shaw: and on fol $94^{\mathrm{b}}$ of Rl. MS., 14, E. III., is an example, the only one ever observed by the writer, of a lozenge-formed ailette. (See cut.) It is clear, from the cross on the shield having the same position as the other, that the ailette is not a square one worn askew.

The size of this appendage differs greatly in different monuments : in the round example of the ivory casket, cited above, it is scarcely larger than the palm of the hand; while in an illumination of Rl. MS., 20, D. 1 (fol. $18^{\mathrm{b}}$ ), it is nearly as large as the ordinary shield of the period. Its position is generally behind the shoulder or at the side of it, sometimes in front; but too strict an interpretation must not be given to the rude memorials of these times. 
The use of this "accessoire" has somewhat puzzled antiquarian writers. In the present day the French archaeologists confess that it is " difficile d'en expliquer l'usage." (Annales Archeol., vol. iv., 212.) Some writers have considered it as a simply defensive provision; others look upon it as an ensign, to indicate to his followers the place of a leader in the field. Against the notion that it was merely armorial, may be urged that in many cases it has no heraldic bearing at all : sometimes it has a cross only, sometimes a diaper pattern, and sometimes it is quite blank. In vellum-paintings it is often seen worn by lnights in the tilt; where the heraldic bearings already exhibited on the shield, crest, and surcoat of the rider and the caparisons of the horse, would to no useful purpose be repeated on the ailette. In the case of the Clehongre example quoted above, the outside fastening of the point does not seem consistent with the idea of armorial display on the wing beneath. Italian writers, however, continue to call these adjuncts Bandiere (Cibrario, Sigilli de' Principi di Savoia). But in Germany they are called Tartsclien (Hefner : Trachten), and their purpose of shields seems most in accordance with the numerous ancient evidences in which they appear. The knights of the middle ages, indeed, not content with their panoply of steel, seem to have fortified themselves with a complete outwork of shields. Thus we have the ailettes, the shield proper, the garde-bras or elbowshield, the shoulder-shield, the Beinschiene or shield for the legs, the vamplate on the lance, and the steel front of the saddle, which was in fact but another shield for the defence of the knight's body. The close analogy of the ailettes (considered as defences) with those curious upright pieces of steel on the shoulders, so frequent in the suits of Henry VIIIth's time, will at once be recognised. Hefner has observed that the introduction of the ailette must be attributed to the French, from the name, "aisles," or "aislettes," under which they appear in contemporary records. Should we not rather say to a nation using the French language? Both the French and Latin names have been preserved to us in documents of their own time. In 1313, the Inventory of the effects of Piers Gaveston (New Fœdera, vol. ii., pt. I., p. 203) has :-

"Item, autres divers garnementz des armes le dit Pieres, ovek les alettes garniz et frettez de perles." 
The Inventory of the goods of Umfrey de Bohun, 1322, printed by Mr. Hudson Turner in the second volume of this work, affords another example :- “iiij. peire de alettes des armes le Counte de Hereford."

The Latin name, aletta, appears in the roll in the Tower, containing the account of articles purchased for the tournament in Windsor Park, 6 of Ed. I., (1278) printed in Archæologia, vol. 17 : “j. par' alett”" (alettarum). And, again :-

"It' p' xxxviij par' alett' s' p' q' par' di' uln' card. s' xix uln',"

These nineteen ells of carda (a kind of cloth), were to cover the leather which formed their substance. Twelve dozen silk cords were provided to attach the ailettes to the shoulders. Sir Roger de Trumpington was one of the knights furnished with ailettes at the Windsor Tournament, and he still wears them in his effigies in Cambridgeshire, though in this case ensigned with the armorial bearings of his house.

J. HEWITT. 